Check for updates

Cite this: RSC Adv., 2018, 8, 34136

Received 11th June 2018

Accepted 26th September 2018

DOI: $10.1039 / c 8 r a 04991 b$

rsc.li/rsc-advances

\section{Simultaneous measurement of multiple organic tracers in fine aerosols from biomass burning and fungal spores by HPLC-MS/MS}

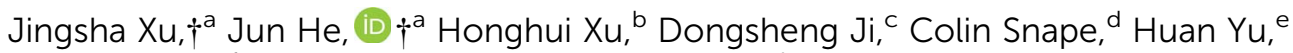 \\ Chunrong Jia, ${ }^{f}$ Chengjun Wang ${ }^{\star g}$ and Jianfa Gao ${ }^{\text {h }}$
}

\begin{abstract}
Three monosaccharide anhydrides (MAs: levoglucosan, mannosan, and galactosan) and sugar alcohols (arabitol and mannitol) are widely used as organic tracers for source identification of aerosols emitted from biomass burning and fungal spores, respectively. In the past, these two types of organic tracer have been measured separately or conjointly using different analytical techniques, with which a number of disadvantages have been experienced during the application to environmental aerosol samples, including organic solvent involved extraction, time-consuming derivatization, or poor separation efficiency due to overlapping peaks, etc. Hence, in this study a more environment-friendly, effective and integrated extraction and analytical method has been developed for simultaneous determination of the above mentioned organic tracers in the same aerosol sample using ultrasonication and high performance liquid chromatography with tandem mass spectrometry (HPLC-MS/MS). The ultrasonication assisted extraction process using ultrapure water can achieve satisfactory recoveries in the range of $100.3 \pm 1.3 \%$ to $108.4 \pm$ $1.6 \%$ for these tracers. All the parameters related to LC and MS/MS have been optimized to ensure good identification and pronounced intensity for each compound. A series of rigorous validation steps have been conducted. This newly developed analytical method using ultrasonication and HPLC-MS/MS has been successfully applied to environmental aerosol samples of different pollution levels for the simultaneous measurement of the above mentioned five organic tracers from biomass burning and fungal spores.
\end{abstract}

\section{Introduction}

Biomass burning is a major contributor to the particulate matter and trace gases found in the atmosphere..$^{1-3}$ In addition, biomass burning can also cause the release of fungal spores into the atmosphere, which may contribute to regional air pollution problems through mid- or long-range transboundary transport and pose adverse health effects such as allergic

${ }^{a}$ Department of Chemical and Environmental Engineering, International Doctoral Innovation Centre, University of Nottingham Ningbo China, Ningbo, P. R. China ${ }^{b}$ Zhejiang Meteorological Science Institute, Hangzhou, P. R. China

${ }^{c}$ State Key Laboratory of Atmospheric Boundary Layer Physics and Atmospheric Chemistry, Institute of Atmospheric Physics, Chinese Academy of Sciences, Beijing, P. R. China

${ }^{d}$ Department of Chemical and Environmental Engineering, Faculty of Engineering, University of Nottingham, University Park, Nottingham NG7 2RD, UK

${ }^{e}$ School of Environmental Science and Engineering, Nanjing University of Information Science and Technology, Nanjing, P. R. China

${ }^{f}$ School of Public Health, University of Memphis, Memphis, TN, USA

${ }^{g}$ College of Chemistry and Materials Engineering, Wenzhou University, Wenzhou, P. $R$. China. E-mail: wang.chengjun@yahoo.com

${ }^{h}$ Queensland Alliance for Environmental Health Sciences, The University of Queensland, Brisbane, Australia

$\dagger$ These authors equally contributed to this work. reactions..$^{4-8}$ Biomass burning was also reported as one of the largest contributors to airborne carbonaceous aerosols. ${ }^{\mathbf{9 - 1 2}}$ Particles emitted from biomass burning can act as cloud condensation nuclei in the atmosphere, change the microphysical and radiative properties and significantly affect the global climate. ${ }^{\mathbf{1 3 , 1 4}}$ Hence, it is important to understand the characteristics of biomass burning related particles.

Water-soluble potassium was proposed as a tracer for biomass burning, ${ }^{\mathbf{1 0 , 1 5 , 1 6}}$ but this tracer is not really unique due to its other potential sources like land or marine origins. ${ }^{17,18}$ Some studies calculated non-sea-salt non-dust $\mathrm{K}^{+}$by eliminating these sources, ${ }^{19,20}$ but this correction approach is based on an assumption that no variability existed among different locations and seasons, which is clearly not applicable in all cases. $^{\text {21,22 }}$ Monosaccharide anhydrides (MAs) including levoglucosan (levo, 1, 6-anhydro- $\beta$-D-glucopyranose) and its isomers mannosan (manno, 1,6-anhydro- $\beta$-D-mannopyranose) and galactosan (gala, 1,6-anhydro- $\beta$-D-galactopyranose) are generated from the incomplete combustion or thermal alteration of cellulose and hemicellulose components of biomass under high temperature $\left(>300{ }^{\circ} \mathrm{C}\right) .{ }^{\mathbf{2 3 , 2 4}}$ These anhydrous sugars, especially levoglucosan, are widely employed as reliable biomass burning tracers because they are highly source specific and relatively stable in the atmosphere. ${ }^{25-27}$ 
To investigate airborne fungal spores, the traditional method based on the colony forming units assay are being used by the researchers. However, this culture method is unable to provide media in fulfilling all specific growth requirements of diverse fungal species. ${ }^{28}$ Microscopic counting is also widely used to quantify fungal spores. ${ }^{29,30}$ Nevertheless, this method can only be performed on Teflon or polycarbonate filters instead of fibrous filter media (quartz or glass fiber filters), which are commonly used for sampling to investigate the chemical composition of aerosols. ${ }^{31}$ Therefore, the application of molecular tracer method has been introduced to simplify sampling and allow different components of particles being determined on the same filter. It has been reported that the steroid ergosterol is considered as a marker for fungi; besides, sugar alcohols including arabitol (ara) and mannitol (manni) constitute energy reserve material in fungi and act as cell reinforcements against stressful conditions, which have also been widely employed as biomarkers. ${ }^{32-36}$ However, as for the estimation of fungal spore concentration in the ambient atmosphere, Filippo et al. (2013) pointed out that ergosterol proved to be the only reliable biomarker for fungi in their study and it should be cautious to apply mannitol and arabitol to quantify fungal contribution to the atmospheric particulate mass as other sources also release the latter two polyols, such as algae, bacteria and lower plants. ${ }^{37}$ On the other hand, arabitol and mannitol are produced in large amounts by many fungi and have shown to be mostly associated with fungal spores, particularly in the continental aerosols. ${ }^{28,38,39}$ Therefore, both mannitol and arabitol should still be applicable as biomarkers to qualitatively identify the possible inputs from fungi to the atmospheric particulate matter. ${ }^{31,38,40,41}$

In recent years, a lot of techniques have been developed to quantify these tracers separately or conjointly (Table 1). The most common technique to analyse MAs is gas chromatography - mass spectrometry (GC-MS) after derivatization using various silylating agents. ${ }^{\mathbf{4 2 , 4 3}}$ Derivatization can increase the volatility and thermal stability, and improve chromatographic properties of the original polar compounds after such a conversion. ${ }^{43}$ The limit of detection (LOD) of levoglucosan was reported to be 130 $\mu \mathrm{g} \mathrm{L}{ }^{-1}$ by GC-MS. ${ }^{44}$ Similar to the analysis of MAs, GC-MS and gas chromatography - flame ionization detector (GC-FID) were also applied to analyse sugar alcohols after derivatization. ${ }^{31,44}$ Urban et al. (2014) applied GC-MS to analyze these tracers conjointly. ${ }^{45}$ However, their study lacked the discussion regarding tracer identification and separation, and this method also requires complicated derivatization as the pre-treatment process before the GC-MS analysis. GC-MS technique, as mentioned before, is a common analytical method for the analysis of these tracers, yet it is time-consuming and also may cause the analyte loss due to the derivatization process; ${ }^{\mathbf{4 6}-48}$ though good LODs can be achieved in some studies, they failed to completely separate these tracers, which could cause bias to the final results without using tandem mass spectrometer for further peak identification. ${ }^{49-52}$ A number of analytical methods of MAs without derivatization have been developed in the past decade. In the study of Yttri et al. (2011), they applied High Performance Liquid Chromatography with High Resolution
Mass Spectrometry Time-of-Flight (HPLC/HRMS-TOF) to analyze these five tracers, ${ }^{53}$ but these tracers were not analyzed simultaneously as different columns were used to analyze MAs and sugar alcohols, and the extraction procedure of MAs and sugar alcohols were not the same. Particle-into-liquid sampler high-performance anion-exchange chromatography - mass spectrometry (PILS-HPAEC-MS) is a fast online determination equipment for analysing levoglucosan, the LOD of which is approximately $5-10 \mu \mathrm{g} \mathrm{\textrm {L } ^ { - 1 }}$, but its concentration is often underestimated for about $20 \% .^{54}$ Ion chromatography coupled with pulsed amperometric detector (IC-PAD) achieved the LOD of levoglucosan being only $60 \mu \mathrm{g} \mathrm{L}^{-1}\left(200 \mathrm{ng} \mathrm{m}^{-3}\right) .{ }^{55}$ Highperformance liquid chromatography - pulsed amperometric detector (HPLC-PAD) achieved the LODs for the above mentioned three MAs and two sugar alcohols in the range of 10$30 \mu \mathrm{g} \mathrm{L}^{-1}$, but a serious overlap was found between arabitol and levoglucosan. ${ }^{50}$ Better LODs were obtained by high-performance anion-exchange chromatography - mass spectrometry (HPAECMS) with $2 \mu \mathrm{g} \mathrm{L}^{-1}, 1 \mu \mathrm{g} \mathrm{\textrm {L } ^ { - 1 }}$, and $1 \mu \mathrm{g} \mathrm{\textrm {L } ^ { - 1 }}$ for levoglucosan, mannosan and galactosan, respectively, in spite of small overlap observed for levoglucosan and mannosan. ${ }^{\mathbf{4 9}}$ These five tracers were also simultaneously measured by highperformance anion-exchange chromatography - pulsed amperometric detector (HPAEC-PAD) with good LODs, but a small overlap between levoglucosan and arabitol was found. ${ }^{\mathbf{5 6}}$ Several studies applied liquid chromatography coupled with mass spectrometry to investigate levoglucosan, mannosan and galactosan, but unsatisfactory separation always occurred. ${ }^{\mathbf{1 1 , 5 2 , 5 7}}$ Piot et al. (2012) applied HPLC-MS/MS to successfully separate and determine the three MAs, however, they used sodium hydroxide as the eluent which would possibly block the electrode due to crystallization effect of this alkaline solution under high temperature at the ion source and cause non-uniform spray; besides, the LODs of MAs were $30 \mu \mathrm{g} \mathrm{L} \mathrm{L}^{-1}$, LOQs were $100 \mu \mathrm{g} \mathrm{L}^{-1}$, which were not so applicable to those less-polluted aerosol samples. ${ }^{58}$ HPLC-MS/MS has also been applied to analyse fungal spore tracers like arabitol and mannitol using accelerated solvent extraction with pure ethanol, the LOD of which was however not reported..$^{\mathbf{4 1}}$

Hence, it has been challenging to analyze the abovementioned five organic tracers simultaneously in the same aerosol sample with pronounced intensities. To fill such a gap, ultrasonication and high performance liquid chromatography with tandem mass spectrometry (HPLC-MS/MS) were to be employed in this study and the primary objective was to develop an organic solvent free extraction process and a simultaneous analytical method with good separation, high mass selectivity and sensitivity for the identification and quantification of target compounds including three primary biomass burning tracers (levoglucosan, mannosan, and galactosan), and two fungal spore tracers (arabitol, and mannitol).

\section{Experimental}

\section{Instrument, chemicals and materials}

The instrument applied in this study was High Performance Liquid Chromatograph (Shimadzu 30A) - Tandem Mass 


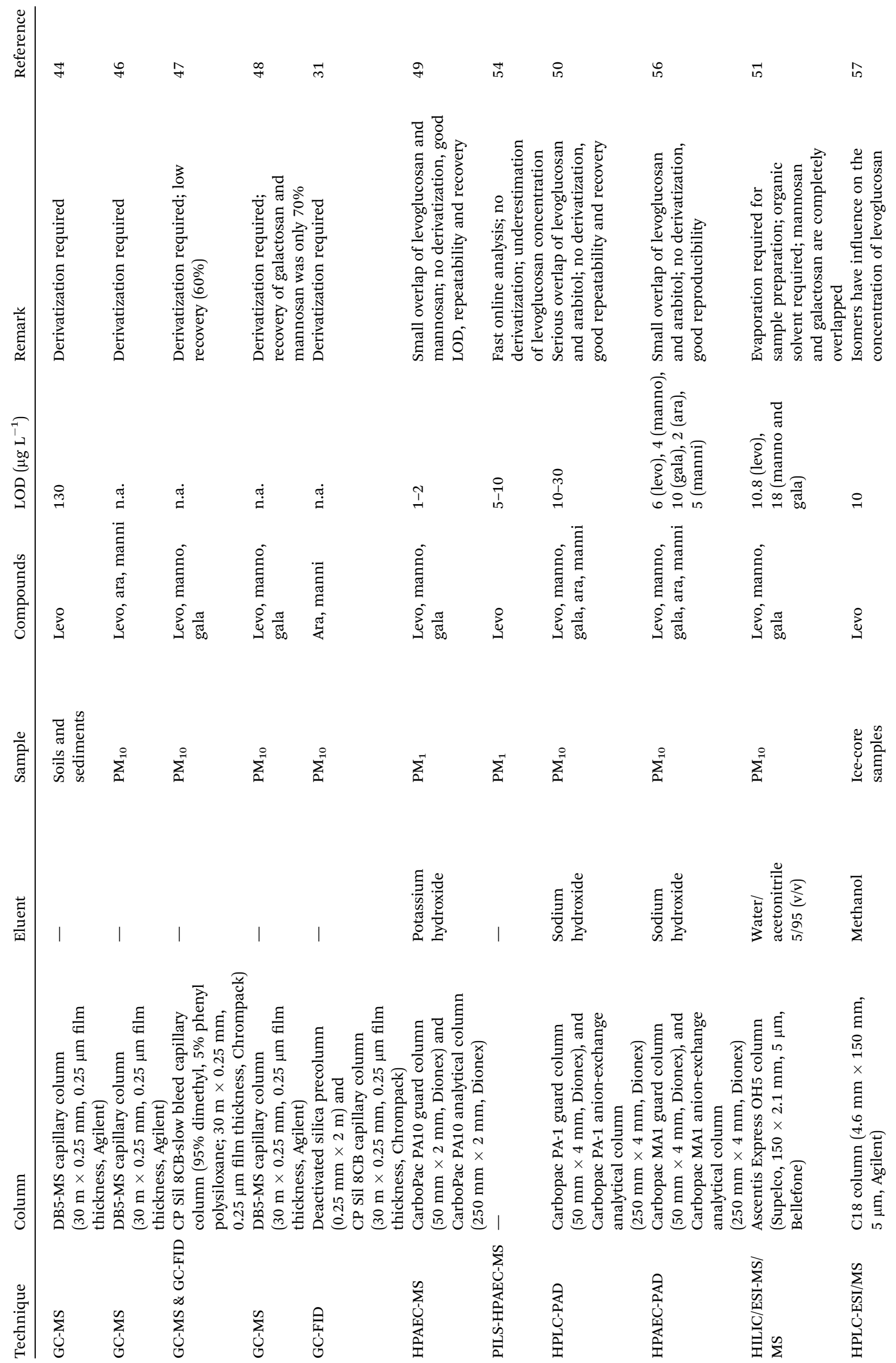




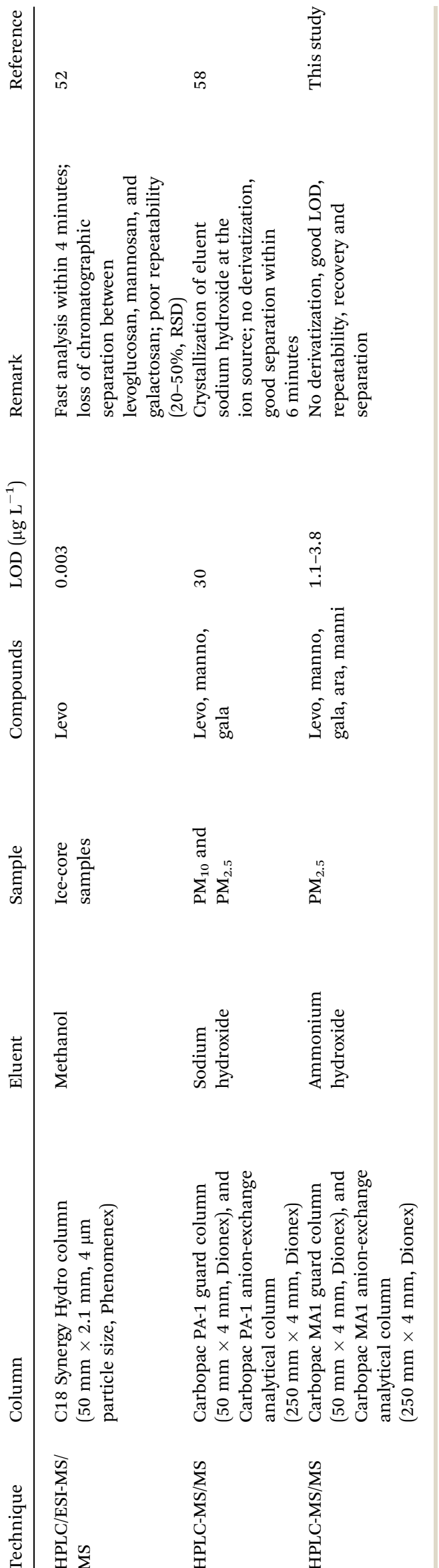

Spectrometry (ABSciex $3200 \mathrm{Q}$ trap) (HPLC-MS/MS) equipped with Electrospray Ionization (ESI). The separation of target compounds was achieved by an anion-exchange analytical column (Dionex, Carbopac MA1, $250 \mathrm{~mm} \times 4 \mathrm{~mm}$ ) and a guard column (Dionex, Carbopac MA1, $50 \mathrm{~mm} \times 4 \mathrm{~mm}$ ). These columns were chosen due to their ability for the separation of both monosaccharides and sugar alcohols. Ammonium hydroxide $\left(\mathrm{NH}_{3} \cdot \mathrm{H}_{2} \mathrm{O}, 25 \% \mathrm{NH}_{3}\right.$ in $\mathrm{H}_{2} \mathrm{O}$, HPLC level, SigmaAldrich) was applied as the eluent for separation, the concentration of which could be changed through the proportion alternation of mobile phases in two pumps: pump A (ammonium hydroxide) and pump B (ultrapure water). Authentic standards applied in this study include levoglucosan (99.0\%, CAS 498-07-7, Sigma-Aldrich, Shanghai, China), mannosan (98.0\%, CAS 1416865-1, Sigma-Aldrich, Shanghai, China), galactosan (97.0\%, CAS 644-76-8, BOC Sciences, USA), arabitol (99.9\%, CAS 488-82-4, Sigma-Aldrich, Shanghai, China) and mannitol (99.0\%, CAS 6965-8, Sigma-Aldrich, Shanghai, China), and their chemical structure are presented in Fig. 1. The internal calibration standard used was C-13 labelled mannitol (mannitol- $1{ }^{13} \mathrm{C}, 99.0 \%$, CAS 132202-29-0, J\&K, Shanghai, China). Since all target compounds are highly water soluble, and the columns selected were not compatible with organic solvents ${ }^{59}$ all solutions in this study were prepared with $18.2 \Omega$ ultrapure water. This ultrapure water was ultrasonically degassed before preparation of ammonium hydroxide solution in order to reduce air bubbles in the elution before entering LC system, ${ }^{60}$ and minimize the effect of dissolved $\mathrm{CO}_{2}$, which could disturb chromatographic performance through the formation of carbonate. ${ }^{17,61-63}$

\section{Standard solution preparation}

$1000 \mathrm{mg} \mathrm{L}^{-1}$ stock solutions of levoglucosan, mannosan, galactosan and $100 \mathrm{mg} \mathrm{L}^{-1}$ stock solutions of arabitol, mannitol and mannitol-1- ${ }^{13} \mathrm{C}$ were prepared in ultrapure water. Working solutions $\left(10 \mu \mathrm{g} \mathrm{L}^{-1}\right.$ to $\left.10 \mathrm{mg} \mathrm{L}^{-1}\right)$ and external calibration standard solutions of these compounds were freshly prepared prior to analysis by diluting above-mentioned stock solutions with ultrapure water. The mixed calibration standard solutions were made by combining the aliquots of each compound stock solution and diluting with ultrapure water, resulting in mixed

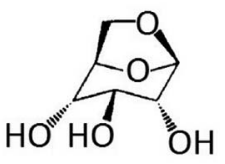

Levoglucosan

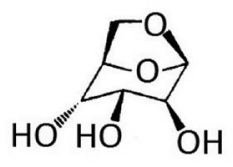

Mannosan

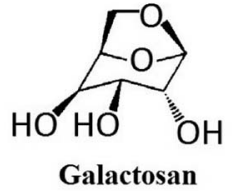

Galactosan<smiles>OC[C@@H](O)C(O)[C@H](O)CO</smiles>

Arabitol<smiles>OC[C@@H](O)[C@@H](O)[C@H](O)[C@H](O)CO</smiles>

Mannitol
Fig. 1 Chemical structures of levoglucosan, mannosan, galactosan, arabitol and mannitol. 
standards at the levels of $0.01,0.02,0.05,0.1,0.2,0.5$ and $1 \mathrm{mg} \mathrm{L}{ }^{-1}$. Internal calibration standard mannitol- $-1{ }^{13} \mathrm{C}$ was added into the hybrid standards before diluting with ultrapure water to give final concentration of $1 \mu \mathrm{g} \mathrm{mL}{ }^{-1}$ mannitol- $-{ }^{-13} \mathrm{C}$ in all standards. All solutions were stored in refrigerator at $4{ }^{\circ} \mathrm{C}$ until analysis. The linearity of calibration curves of each analyte was investigated and regularly checked throughout the entire analysis. ${ }^{64}$ Quality control (QC) samples were independently prepared as the calibration standards to give three levels of concentration, including low, medium and high concentra-

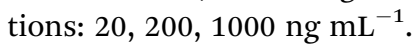

\section{Sample collection and extraction}

$\mathrm{PM}_{2.5}$ samples were captured on $90 \mathrm{~mm}$ quartz fiber filters (QMA, Whatman, UK) by a medium volume $\mathrm{PM}_{2.5}$ samplers (model: TH-150CIII, Tianhong Instrument CO., Ltd. Wuhan, China), operating for 24 hours at a flow rate of $80 \mathrm{~L} \mathrm{~min}^{-1}$ at the atmospheric observation station ( $15 \mathrm{~m}$ above the ground level) in University of Nottingham Ningbo China in December 2014, January, June and July 2015. After collection, aerosol samples were wrapped in aluminium foil, sealed in polyethylene bags and stored at $-18{ }^{\circ} \mathrm{C}$ until analysis. Prior to any usage, all fresh filters were pre-baked in a muffle furnace at $550{ }^{\circ} \mathrm{C}$ for 5 hours to remove any organic compounds. Before gravimetric measurement, filters were equilibrated at constant temperature $\left(22{ }^{\circ} \mathrm{C} \pm 1{ }^{\circ} \mathrm{C}\right)$ and relative humidity $(30 \% \pm 5 \%)$ for $24 \mathrm{~h}$. Then the $\mathrm{PM}_{2.5}$ mass on $90 \mathrm{~mm}$ quartz fiber filters were measured by an ultra-microbalance (model: SE2-F, Sartorius, precision 0.1 $\mu \mathrm{g}$ ) in the same micro-balance room.

To extract samples, one-eighth of the $90 \mathrm{~mm}$ filters were extracted ultrasonically by $4 \mathrm{~mL}$ ultrapure water for 45 minutes under room temperature, and the extracts were then filtered with $0.25 \mu \mathrm{m}$ membrane filters and stored at $4{ }^{\circ} \mathrm{C}$ until HPLCMS/MS analysis within one week.

\section{Results and discussion}

\section{Method development}

The steps in developing the HPLC-MS/MS analytical method are summarized as follows: (1) use tandem mass spectrometry (MS/
MS) and manually adjust the ion source and compound parameters to identify the representative parent ions and product ions of each compound; (2) combine HPLC with MS/ MS, apply the MS parameters acquired from previous step and optimize LC parameters (eluent concentration, eluent flow rate, gradient flow and column oven temperature) to achieve the best separation and highest peak intensity of representative parent with daughter (product) ion pairs in the multiple reaction monitoring (MRM) mode; (3) continue to use HPLC-MS/MS and apply above optimized LC parameters, use flow injection analysis (FIA) to obtain more precise MS parameters of interest. The optimized LC parameters in step (2) and MS parameters in step (3) would comprise the final HPLC-MS/MS method.

\section{Identification of representative parent and product ions}

$5 \mathrm{mg} \mathrm{\textrm {L } ^ { - 1 }}$ of levoglucosan, mannosan, galactosan, arabitol, mannitol and mannitol- $-1{ }^{13} \mathrm{C}$ were introduced to the mass spectrometry separately to find out their representative parent ions and product ions. MS parameters include ion source parameters, and compound parameters were manually adjusted to obtain good parent ion peak intensity and the best Collision Induced Dissociation (CID) efficiency with selective current of product ions. The mass charge ratio $(\mathrm{m} / \mathrm{z})$ of each ion is accurate to 0.1 amu (atomic mass units). Individually, levoglucosan, mannosan and galactosan have the same parent ion $m / z 160.9$, and those for arabitol, mannitol and mannitol- $1-{ }^{13} \mathrm{C}$ were $\mathrm{m} / \mathrm{z}$ 151.0, $\mathrm{m} / \mathrm{z} 181.0$ and $\mathrm{m} / \mathrm{z} 182.0$, respectively. The parent and product ions for levoglucosan, mannosan, galactosan, arabitol, mannitol and mannitol-1-13 $\mathrm{C}$ were presented in Table 2. The MRM acquisition mode was applied to acquire two or more diagnostic product ions from the chosen parent ions (as mentioned above) to obtain high selectivity and sensitivity. The data were collected in negative ion mode with a $200 \mathrm{~ms}$ dwell time/transition. The injection volume was $10 \mu \mathrm{L}$. The parent ions were selected in the first quadrupole (Q1) in MS and the product ions of interest were selected in the third quadrupole (Q3) in MS.

\section{Optimization of LC parameters}

Anion-exchange analytical columns were used for separation of these compounds. Given its compatibility requirement,

Table 2 Analytical parameters of each organic tracer in MRM mode of HPLC-MS/MS

\begin{tabular}{|c|c|c|c|c|c|c|c|c|}
\hline Tracers & $\mathrm{RT}^{a}(\min )$ & Parent ion & Product ion & $\begin{array}{l}\text { Declustering } \\
\text { potential } \\
\text { DP }(V)\end{array}$ & $\begin{array}{l}\text { Entrance } \\
\text { potential } \\
\text { EP }(V)\end{array}$ & $\begin{array}{l}\text { Collision cell } \\
\text { entrance potential } \\
\text { CEP (V) }\end{array}$ & $\begin{array}{l}\text { Collision } \\
\text { energy } \\
\text { CE (V) }\end{array}$ & $\begin{array}{l}\text { Collision cell } \\
\text { exit potential } \\
\mathrm{CXP}(\mathrm{V})\end{array}$ \\
\hline \multirow[t]{2}{*}{ Levo } & \multirow[t]{2}{*}{19.8} & $160.9^{b}$ & $101.0 *$ & -45 & -2.2 & -9 & -15 & -1.7 \\
\hline & & 160.9 & 113.0 & -42 & -2.0 & -6 & -13 & -2.2 \\
\hline \multirow[t]{2}{*}{ Manno } & \multirow[t]{2}{*}{43.0} & 160.9 & 101.0 & -45 & -2.2 & -9 & -15 & -1.7 \\
\hline & & 160.9 & 129.0 & -38 & -3.2 & -6 & -13 & -2.2 \\
\hline \multirow[t]{2}{*}{ Gala } & \multirow[t]{2}{*}{59.9} & 160.9 & 101.0 & -45 & -2.2 & -9 & -15 & -1.7 \\
\hline & & 160.9 & 113.0 & -42 & -2.3 & -12 & -13 & -1.7 \\
\hline \multirow[t]{2}{*}{ Ara } & \multirow[t]{2}{*}{24.5} & 151.0 & 71.0 & -32 & -2.5 & -10 & -25 & -1.2 \\
\hline & & 151.0 & 59.0 & -30 & -3.0 & -10 & -28 & -1.0 \\
\hline \multirow[t]{2}{*}{ Manni } & \multirow[t]{2}{*}{48.3} & 181.0 & 89.1 & -32 & -2.8 & -15 & -20 & -1.7 \\
\hline & & 181.0 & 71.0 & -32 & -2.2 & -8 & -30 & -1.2 \\
\hline
\end{tabular}

${ }^{a}$ Retention time. ${ }^{b}$ The ion pairs highlighted in bold were used for the quantification of each compound. 
hydroxide eluent is needed as a mobile phase. Sodium hydroxide, as a non-volatile compound, will crystallize under high temperature and very possibly block the ion source to cause non-uniform spray, which deems not suitable as an eluent for LC-MS unless it is equipped with a desalting unit upstream. Hence, in this study, the suitability of ammonium hydroxide was explored. The preliminary tests showed that the gradient elution of ammonium hydroxide has little impact on the peak separation, thus the optimization of LC parameters is based on column oven temperature, eluent flow rate and concentration.

(1) Column oven temperature. According to single variable principle, the column oven temperature was the only parameter to be optimized in this step. MS parameters were not changed after the acquisition of parent and product ions from previous step. The applied eluent was $0.001 \% \mathrm{NH}_{3} \cdot \mathrm{H}_{2} \mathrm{O}$ with isocratic flow rate at $0.4 \mathrm{~mL} \mathrm{~min}^{-1}$. The applicable temperature range of the columns is $4-50{ }^{\circ} \mathrm{C}^{\mathbf{6 1}}$ to ensure consistent good performance of the columns, the temperature should not be higher than $90 \%$ of its maximum. Therefore, the column oven temperature was optimized at $25,30,35,40$ and $45{ }^{\circ} \mathrm{C}$. When the temperature was lower than $35{ }^{\circ} \mathrm{C}$, the separation of mannosan and galactosan was not satisfactory. As the parentproduct ion pair (160.9-101.0) selected for both was the same, it was impossible for identification and quantification when they were overlapped. Therefore, only $40{ }^{\circ} \mathrm{C}$ and $45{ }^{\circ} \mathrm{C}$ were considered to achieve this purpose. Regarding the peak intensity, levoglucosan was observed with highest intensity under $40{ }^{\circ} \mathrm{C}$, while others were with highest intensities at $45{ }^{\circ} \mathrm{C}$. The ambient concentrations of mannosan, galactosan, arabitol and mannitol are usually lower than levoglucosan. Therefore, to make sure they all can be detected at trace levels in the same aerosol sample, $45{ }^{\circ} \mathrm{C}$ was finally selected and applied in this study.

(2) Eluent flow rate. It has been well established that operating ESI at low flow rates improves ionization efficiency while the ion transmittance current at the ESI interface could increase at higher flow rates to some extent. ${ }^{65-67}$ Though these MAs are stereoisomers with similar physical and chemical properties, it is still possible for them to respond to the change of flow rates slightly differently in terms of both ionization and transmission efficiencies, which may lead to the maximum peak intensity of each individual analyte at different optimum flow rate. Hence the flow rate optimization was necessary in this study.

The flow rate applicable to the columns is in the range of $0.2-$ $0.5 \mathrm{~mL} \min ^{-1} \cdot{ }^{61}$ However, during the optimization process, the column pressure occasionally reached its limit (2000 psi) when the $0.45 \mathrm{~mL} \mathrm{~min}^{-1}$ was applied as the flow rate. Hence, the flow rates for optimization were set as $0.2,0.25,0.3,0.35$ and 0.4 $\mathrm{mL} \min ^{-1}$. At 0.35 and $0.4 \mathrm{~mL} \min ^{-1}$, the intensities of most organic tracers were higher than those acquired at other flow rates; eventually $0.4 \mathrm{~mL} \mathrm{~min}^{-1}$ was selected as optimum flow rate, which is also beneficial to the reduction of analysis time per sample while the good separation is still achieved.

(3) Eluent concentration. In this step, the column oven temperature and eluent flow rate were set as $45{ }^{\circ} \mathrm{C}$ and 0.4
$\mathrm{mL} \min ^{-1}$, respectively. The optimization results regarding eluent concentration was plotted as shown in Fig. 2. It shows that levoglucosan, with the highest intensity among all tracers, was highly affected by the change of ammonium hydroxide solution, and its intensity increased as the eluent concentration increased in the range of $0.00001-0.001 \%$. The peak intensities of mannosan and galactosan were the highest when the eluent concentration is $0.0005 \%$. However, arabitol and mannitol were observed with the highest peak intensity when eluent concentration was $0.0001 \%$. Because the peak intensities of arabitol and mannitol were lower than those of the three MAs, and the ambient concentrations of arabitol and mannitol were generally lower than MAs, consistent with the published studies. ${ }^{\mathbf{5 0 6 8 - 7 0}}$ Therefore, to ensure all five tracers can be detectable in the same aerosol sample of low levels, the optimum ammonium hydroxide concentration was selected as $0.0001 \%$ (approximately $0.0528 \mathrm{mmol} \mathrm{L}^{-1}$ ).

\section{Optimization of MS parameters through FIA analysis}

After the optimization of LC conditions, corresponding MS parameters need to be adjusted as well to achieve the best peak intensity. Flow injection analysis (FIA) was applied in this study to automatically optimize the MS parameters of interest, under which the highest peak intensities could be achieved eventually. The ion sources parameters after optimization are listed as follows: curtain gas (CUR), $46.0 \mathrm{psi}$; ion spray voltage (IS), $-3800 \mathrm{~V}$; source temperature (TEM), $650{ }^{\circ} \mathrm{C}$; Ion source gas $1 /$ nebulizer gas (gas 1), $38 \mathrm{psi}$; ion source gas 2/auxiliary gas (gas 2), 80 psi. Detailed information of the optimized method is presented in Table 2, including the retention times (RT), the parent and product ions and the compound parameters of the tracers.

\section{Method performance}

The HPLC-MS/MS MRM chromatogram and Q1/Q3 (parentproduct ion pairs) mass spectrometry on selective $m / z$ of levoglucosan, mannosan, galactosan, arabitol, mannitol and mannitol-1- ${ }^{13} \mathrm{C}$ in $1 \mathrm{mg} \mathrm{L}{ }^{-1}$ standard solution are shown in Fig. 3. Each ion pair was corresponding to a line in the

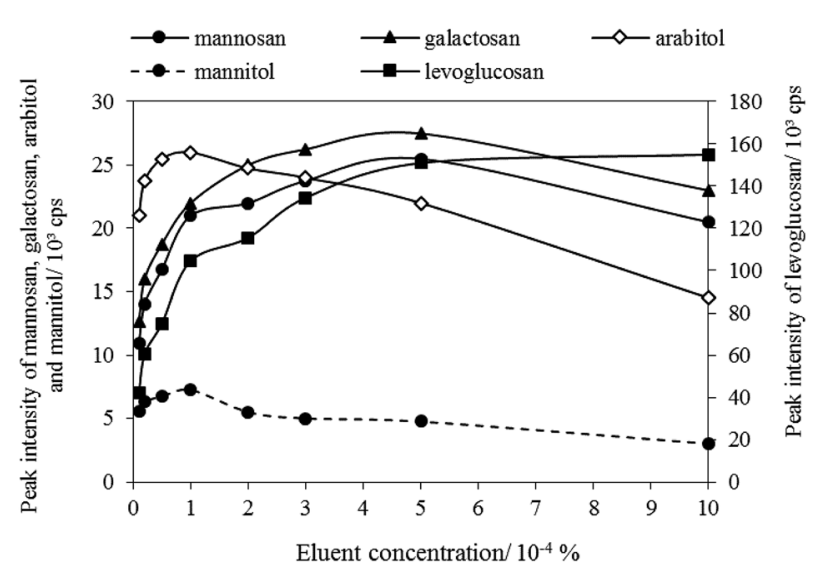

Fig. 2 Eluent concentration optimization. 

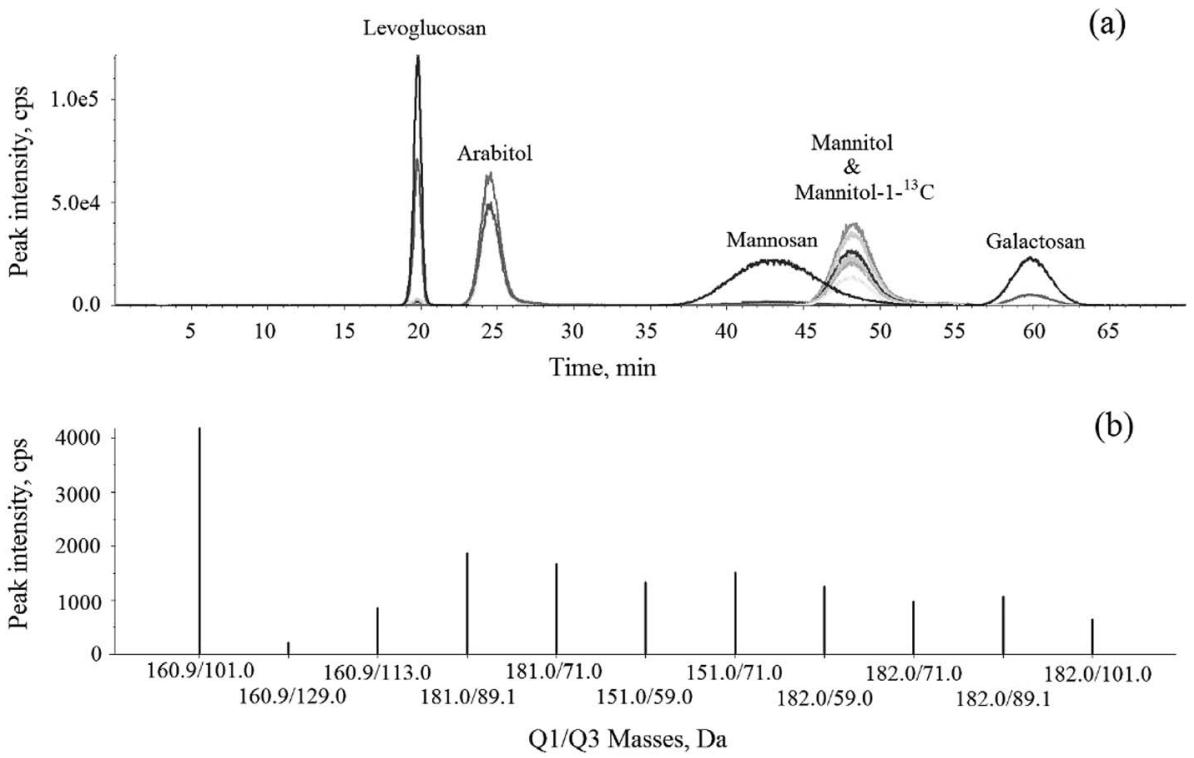

Fig. 3 The HPLC-MS/MS (a) MRM chromatogram and (b) Q1/Q3 mass spectrometry on selective $\mathrm{m} / \mathrm{z}$ of levoglucosan, mannosan, galactosan, arabitol, mannitol and mannitol-1- ${ }^{13} \mathrm{C}$ in $1 \mathrm{mg} \mathrm{L}^{-1}$ standard solution.

chromatogram and could be extracted separately. The ones with the highest intensity of each compound were chosen for their quantification respectively, shown in bold in Table 2 . The resulting chromatogram exhibit good separations for levoglucosan, arabitol and galactosan, but the peaks of mannosan and mannitol were partially overlapped in the figure, moreover, mannitol and mannitol- $-1{ }^{13} \mathrm{C}$ shared the same retention time. However, as mannosan, mannitol and mannitol- $-1{ }^{13} \mathrm{C}$ have completely different representative parent-product ion pairs, and each ion pair can be extracted from the chromatogram individually in MRM mode, therefore their quantifications are not affected through the integration of respective peak areas, which demonstrates the advantageous selectivity of tandem mass spectrometry.

\section{Method validation}

Validation of this method was conducted in terms of the following aspects: linearity, sensitivity, selectivity, specificity, accuracy and precision, extraction recovery, matrix effect, reproducibility and stability. The LOD, calibration curves, extraction recovery and reproducibility of the five above mentioned organic tracers and internal standard mannitol$1-^{13} \mathrm{C}$ are presented in Table 3.

\section{Linearity, sensitivity, selectivity and specificity}

As shown in Fig. 4, the calibration curves of these compounds demonstrated excellent linearity with linear correlation coefficients $(R)>0.999$ in the concentration range of $0.01-1 \mathrm{mg} \mathrm{L}^{-1}$. The LOD can be used to evaluate the sensitivity of the method, which was calculated as the concentration that corresponds to three times the standard deviation of the peak areas produced by filter blanks spiked with certain amount of standards. ${ }^{7-75} \mathrm{In}$ this study, to evaluate LODs, $20 \mu \mathrm{L}$ of $2 \mathrm{mg} \mathrm{L}^{-1}$ standard solutions were spiked on blank filters to result in $10 \mu \mathrm{g} \mathrm{L} \mathrm{L}^{-1}$ of the standards in extracts. The LODs of these compounds range from $1.1 \mu \mathrm{g} \mathrm{L}^{-1}$ for levoglucosan to $3.8 \mu \mathrm{g} \mathrm{L}^{-1}$ for arabitol, as presented in Table 3. These results indicate that this method is sufficiently sensitive for the analysis of target biomarkers in aerosol samples.

Table 3 The LOD, calibration curve, recovery and reproducibility of five tracers by HPLC-MS/MS in MRM mode

\begin{tabular}{|c|c|c|c|c|c|c|c|}
\hline \multirow[b]{2}{*}{ Compounds } & \multicolumn{2}{|l|}{ LOD } & \multicolumn{2}{|c|}{ Calibration curve } & \multirow[b]{2}{*}{$\begin{array}{l}\text { Extraction }^{b} \\
\text { recovery } \%\end{array}$} & \multicolumn{2}{|c|}{ Reproducibility } \\
\hline & $\begin{array}{l}\text { Injected } \\
\text { volume }(\mu \mathrm{L})\end{array}$ & $\begin{array}{l}\text { Extract conc. } \\
\left(\mu \mathrm{g} \mathrm{L}^{-1}\right)\end{array}$ & $\begin{array}{l}\text { Conc. range } \\
\left(\mathrm{mg} \mathrm{L}^{-1}\right)\end{array}$ & $R$ & & Area $^{c}$ RSD $\%$ & Area $^{d}$ RSD $\%$ \\
\hline Levo & 10 & 1.1 & $0.01-1$ & 0.9992 & $108.4 \pm 1.6$ & 2.0 & 0.6 \\
\hline Ara & 10 & 3.8 & $0.01-1$ & 0.9998 & $101.3 \pm 2.3$ & 1.4 & 0.4 \\
\hline Manno & 10 & 2.3 & $0.01-1$ & 0.9999 & $104.7 \pm 1.8$ & 1.9 & 7.7 \\
\hline Gala & 10 & 1.2 & $0.01-1$ & 0.9999 & $106.5 \pm 1.9$ & 1.6 & 5.1 \\
\hline
\end{tabular}

${ }^{a}$ Not available. ${ }^{b}$ Recovery of spiked standards (mean $\pm \mathrm{SD}$ ). ${ }^{c}$ Standard solutions, $n=5 .{ }^{d}$ Atmospheric aerosol samples, $n=4$. 


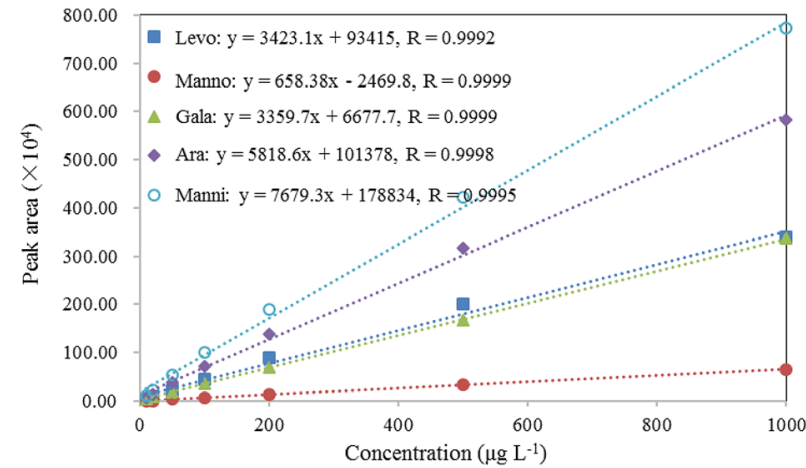

Fig. 4 Calibration curves, correlation coefficient $(R)$ of levoglucosan, mannosan, galactosan, arabitol and mannitol.

All analytes were identified by both each individual's retention time and specific MRM transitions. MRM in LC-MS/MS is very powerful to identify and specify target compounds in complex matrices, ${ }^{76}$ as only specific parent and product ions (parent mass $\rightarrow$ fragment mass) are selected to be examined. The selectivity of this method was evaluated by comparing the chromatograms acquired from extracts of field blanks and environmental aerosol samples and prepared standard solutions, ${ }^{77,78}$ as shown in Fig. 5. Because it is difficult to recognize interference signals from matrices, Hess et al. (2018) recommended that it is better to analyse more than 20 matrices to evaluate possible selectivity problems for endogenous substances. ${ }^{79}$ In this study, we analysed more than 40 blanks, which were collected from different representative areas, such as rural, urban and suburban areas, on seasonal basis (unpublished data from our other study). A typical chromatogram from these field blank samples was chosen and presented in Fig. 5. For better presentation, the peak intensities of arabitol, mannosan, mannitol and galactosan in the sample chromatograms were enlarged by 10 times due to their relatively lower concentrations in aerosol samples. No interference was observed at the retention times of these biomarkers in field blank. Additionally, the peak properties such as retention time and peak shape of these compounds in aerosol sample were observed with high consistence with those in standard solution, which indicates reliable selectivity and specificity of this newly developed method.

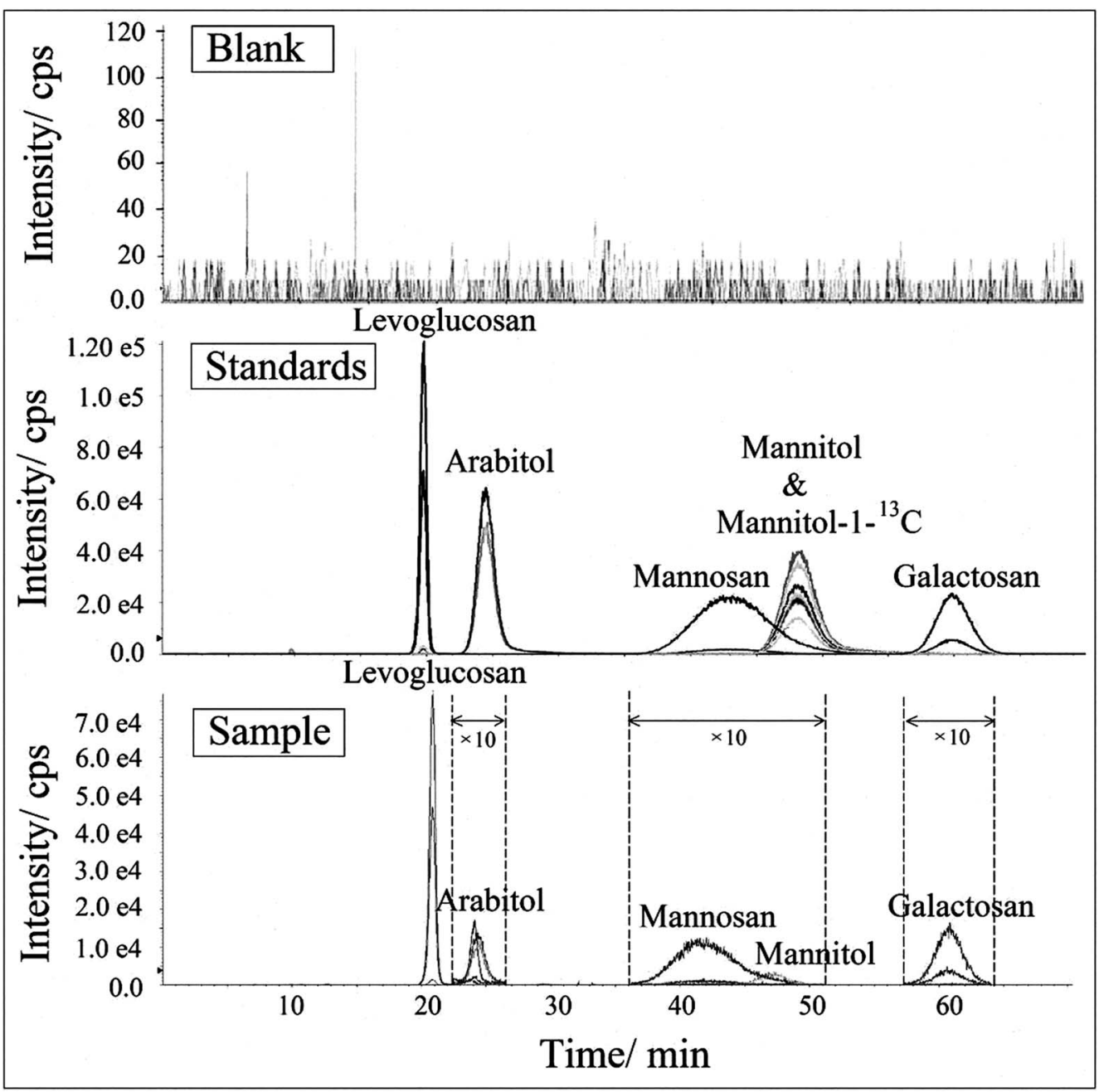

Fig. 5 The HPLC-MSMS chromatogram of levoglucosan, mannosan, galactosan, arabitol, mannitol and mannitol-1- ${ }^{13} \mathrm{C}$ on selective $\mathrm{m} / \mathrm{z}$ in standard and sample extracts (including both blank and environmental samples). 


\section{Accuracy and precision}

The inter- and intra-day accuracy and precision were estimated by analyzing three replicates at low $\left(20 \mathrm{ng} \mathrm{mL}^{-1}\right)$, medium $(200$ $\mathrm{ng} \mathrm{mL}^{-1}$ ) and high (1000 $\mathrm{ng} \mathrm{mL}^{-1}$ ) quality control (QC) levels, as summarized in Table 4 . The intra-day accuracy and precision data was obtained from measurements within one day while the inter-day data was determined on three different days. Accuracy was defined as the percentage of the measured concentration to the nominal concentration of QC samples. Precision is evaluated through the calculation of the coefficient of variation $(\mathrm{CV}$ $(\%)=$ standard deviation/mean $\times 100 \%)$. The intra-day precision was $<10 \%$ for all analytes in low and medium QCs, and high QCs were observed with excellent intra-day precision $(<5 \%)$ for all analytes. The inter-day precision was $<15 \%$ at all QC levels. For intra-day accuracy, low QCs exhibited accuracy $<15 \%$ for most tracers except for mannosan (119\%), the medium and high QCs demonstrated all accuracy within 5\%. The inter-day accuracy was within $10 \%$ for all analytes. These results indicate that the present method is accurate and precise for the determination of levoglucosan, mannosan, galactosan, arabitol and mannitol in aerosol samples.

\section{Extraction recovery}

The extraction recovery of the five target organic tracers were then tested by spiking a certain small amount of stock solutions onto the pre-baked blank filters. The spiked filters were dried at constant temperature $\left(22{ }^{\circ} \mathrm{C} \pm 1{ }^{\circ} \mathrm{C}\right)$ and relative humidity $(30 \%$ $\pm 5 \%$ ) for $24 \mathrm{~h}$ and then extracted in the same way as previously described in Section 2.3, in which the prepared concentrations of $1 \mathrm{mg} \mathrm{L}{ }^{-1}$ for each compound should be produced in final extracts. The extraction recovery of levoglucosan, mannosan, galactosan, arabitol and mannitol were found to be 108.4 $( \pm 1.6) \%, 104.7( \pm 1.8) \%, 106.5( \pm 1.9) \%, 101.3( \pm 2.3) \%$ and $100.3( \pm 1.3) \%$, respectively, as shown in Table 3. The concentrations of these compounds on blank filters were all below detection limits. The high extraction recoveries confirm that ultrapure water instead of organic solvent can be applied to extract these five organic tracers from aerosol samples by ultrasonication efficiently, indicating such an extraction process coupled with the newly developed LC-MS/MS analytical method would be more environment-friendly.

\section{Matrix effect}

The matrix effects of sampling substrate (filter) were roughly evaluated in the following manner. The analytes of interest with the same concentration levels were added into the pre-baked filters and ultrapure water, which were then analyzed by the LC-MS/MS method and the ratio of signals generated by the analytes of interest extracted from standard-spiked filters and those form standard-spiked pure water samples. ${ }^{78,80}$ Three concentrations of $20,100,500 \mu \mathrm{g} \mathrm{L} \mathrm{L}^{-1}$ were tested for matrix effects, with three replicates of each level. The matrix effects of levoglucosan, mannosan, galactosan, arabitol and mannitol were $107.7 \pm 1.3 \%, 102.9 \pm 2.1 \%, 104.7 \pm 1.6 \%, 103.3 \pm 1.0 \%$ and $101.4 \pm 1.5 \%$, respectively, indicating the matrix effects from sampling substrate were insignificant.

\section{Reproducibility}

Reproducibility of this method was also tested for both standard solutions and atmospheric aerosol samples. As shown in Table 3, for consecutive analyses of standard solutions $(n=5)$, the relative standard deviations (RSD\%) of peak area were lower than $2.2 \%$ for all compounds. For consecutive analyses of atmospheric aerosol samples $(n=4)$, the peak area RSD\% of levoglucosan, arabitol and mannitol were $0.6 \%, 0.4 \%$ and $1.8 \%$, respectively. However, higher RSDs were found for mannosan $(7.7 \%)$ and galactosan $(5.1 \%)$ than the former three analytes in the atmospheric aerosol samples, yet in an acceptable range. ${ }^{\mathbf{1 1}}$ This observation was comparable with that reported in the literature (three MAs average: 6.7\%) in aerosol samples for high performance liquid chromatography with aerosol charge detection method. ${ }^{82}$ Hence, the reproducibility of this method

Table 4 Inter- and intra-day precision and accuracy of QC samples $(n=3)$

\begin{tabular}{|c|c|c|c|c|c|c|c|}
\hline \multirow[b]{2}{*}{ Compounds } & \multirow{2}{*}{$\begin{array}{l}\text { Concentration } \\
\left(\mathrm{ng} \mathrm{mL}^{-1}\right)\end{array}$} & \multicolumn{3}{|l|}{ Inter-day } & \multicolumn{3}{|l|}{ Intra-day } \\
\hline & & 20 & 200 & 1000 & 20 & 200 & 1000 \\
\hline \multirow[t]{3}{*}{ Levoglucosan } & Mean $\pm \mathrm{SD}$ & $19.7 \pm 0.1$ & $197.6 \pm 6.3$ & $1009.7 \pm 40.0$ & $20.8 \pm 0.4$ & $206.1 \pm 14.2$ & $1047.1 \pm 43.0$ \\
\hline & $\mathrm{CV}(\%)$ & $0.5 \%$ & $3.2 \%$ & $4.0 \%$ & $2.0 \%$ & $6.9 \%$ & $4.1 \%$ \\
\hline & Accuracy (\%) & $98.5 \%$ & $98.8 \%$ & $110.0 \%$ & $104.0 \%$ & $103.1 \%$ & $104.7 \%$ \\
\hline \multirow[t]{3}{*}{ Mannosan } & Mean $\pm \mathrm{SD}$ & $21.4 \pm 0.8$ & $199.7 \pm 1.9$ & $996.4 \pm 22.8$ & $23.8 \pm 2.0$ & $207.0 \pm 11.7$ & $1044.1 \pm 48.6$ \\
\hline & CV (\%) & $3.7 \%$ & $0.9 \%$ & $2.3 \%$ & $8.3 \%$ & $5.6 \%$ & $4.7 \%$ \\
\hline & Accuracy (\%) & $107.0 \%$ & $99.9 \%$ & $99.6 \%$ & $119.0 \%$ & $103.5 \%$ & $104.4 \%$ \\
\hline \multirow[t]{3}{*}{ Galactosan } & Mean $\pm \mathrm{SD}$ & $21.4 \pm 0.5$ & $200.7 \pm 1.8$ & $997.7 \pm 17.8$ & $22.8 \pm 0.8$ & $210.0 \pm 13.2$ & $1035.1 \pm 42.4$ \\
\hline & CV (\%) & $2.1 \%$ & $0.9 \%$ & $1.8 \%$ & $3.6 \%$ & $6.3 \%$ & $4.1 \%$ \\
\hline & Accuracy (\%) & $107.0 \%$ & $100.4 \%$ & $99.8 \%$ & $114.0 \%$ & $105.0 \%$ & $103.5 \%$ \\
\hline \multirow[t]{3}{*}{ Arabitol } & Mean $\pm S D$ & $19.3 \pm 2.0$ & $194.4 \pm 12.1$ & $978.7 \pm 12.3$ & $21.0 \pm 0.4$ & $203.6 \pm 7.5$ & $1027.5 \pm 33.6$ \\
\hline & CV (\%) & $10.6 \%$ & $6.2 \%$ & $5.4 \%$ & $2.0 \%$ & $3.7 \%$ & $3.3 \%$ \\
\hline & Accuracy (\%) & $96.5 \%$ & $97.2 \%$ & $97.9 \%$ & $105.0 \%$ & $101.5 \%$ & $102.8 \%$ \\
\hline \multirow[t]{3}{*}{ Mannitol } & Mean $\pm \mathrm{SD}$ & $18.6 \pm 2.7$ & $190.7 \pm 20.5$ & $978.1 \pm 24.9$ & $19.4 \pm 1.1$ & $198.9 \pm 11.1$ & $1021.7 \pm 26.7$ \\
\hline & CV (\%) & $14.7 \%$ & $10.8 \%$ & $7.8 \%$ & $5.6 \%$ & $5.6 \%$ & $2.6 \%$ \\
\hline & Accuracy (\%) & $93.0 \%$ & $95.4 \%$ & $97.8 \%$ & $97.0 \%$ & $99.5 \%$ & $102.2 \%$ \\
\hline
\end{tabular}


was considered as good enough for both standard solutions and environmental aerosol samples.

\section{Stability}

Stability of extracts was evaluated using standards spiked blank filters. As presented in Table 5, four different concentrations $\left(10,50,500\right.$ and $\left.1000 \mathrm{ng} \mathrm{mL}^{-1}\right)$ of standards were tested for stability to validate it as a reliable method to analyse the aerosol samples within the linear range. The stability of the QC samples was tested at day 0 , then stored at $4{ }^{\circ} \mathrm{C}$ and re-measured at day 1 and day 7 . For stability in 24 hours, each concentration of the analytes in four replicates was measured immediately after extraction and filtration and re-measured after $24 \mathrm{~h}$ storage at $4{ }^{\circ} \mathrm{C}$. Then, the QC samples were stored at $4{ }^{\circ} \mathrm{C}$ again until analysis at day 7 . In this study, both RSD and relative error (RE) were applied to statistically assess the extract stability. Based on the principles for analytical method validation, both RSD and $\mathrm{RE}$ within $15 \%$ are widely recognized and employed as an acceptance criteria for such an evaluation. ${ }^{83-86}$ The RE was calculated using the following formula:

$\mathrm{RE}=[$ (measured concentration at day 1 or day $7-$ measured concentration at day 0 )/measured concentration at day 0$] \times 100 \%$

The RSDs of levoglucosan, mannosan, galactosan, arabitol and mannitol were in the range of $0.6-6.7 \%$ in measurements after 24 hours, and $0.8-7.3 \%$ in measurements after one week. The stability evaluation showed a slight decrease of analyte concentrations after storing at $4{ }^{\circ} \mathrm{C}$ for one week. Few negative values of REs were observed for arabitol and mannitol after a short-term storage, which was probably the result of volatilization of sugar alcohols. However, both RSDs and REs of all biomarkers at different concentration levels were all within $10 \%$ and met the abovementioned performance criteria. Hence, sample extracts can be stored for a short period of time at $4{ }^{\circ} \mathrm{C}$ (i.e. 7 days) prior to HPLC-MS/MS analysis without major adverse effects on the experimental results.

\section{Method application to the environmental aerosol samples}

Levoglucosan, mannosan, galactosan, arabitol and mannitol were determined in the atmospheric aerosol samples collected in Ningbo during winter (December 2014 to January 2015) and summer periods (June-July 2015). All the daily $\mathrm{PM}_{2.5}$ concentrations are presented in Table 6. As benchmarked against the Chinese Ambient Air Quality Standards (CAAQS, level 2 applicable for residential, commercial, industrial and rural areas) daily $\mathrm{PM}_{2.5}$ threshold of $75 \mu \mathrm{g} \mathrm{m} \mathrm{m}^{-3}$, the winter sampling period experienced moderate to high aerosol pollution levels with an average $\mathrm{PM}_{2.5}$ concentration of $88.1 \pm 24.3 \mu \mathrm{g} \mathrm{m} \mathrm{m}^{-3}$ ranging from 47.5 to $127.4 \mu \mathrm{g} \mathrm{m}^{-3}$, while much lower aerosol pollution was observed during the summer season with an average $\mathrm{PM}_{2.5}$ concentration of $27.2 \pm 6.4 \mu \mathrm{g} \mathrm{m}^{-3}$ in the range of $17.0-36.1 \mu \mathrm{g}$ $\mathrm{m}^{-3}$. Fig. 5 shows a representative chromatogram of five tracers from an aerosol sample and a mixed standard solution. As can be seen in Fig. 5, these compounds are undetectable in field blank filters. Table 6 additionally summarizes the concentrations all biomarkers of interest in aerosol samples during winter and summer seasons. To attain good quality assurance and control, for the daily analysis of one batch aerosol samples, a new calibration curve was always established the beginning of measurement. In addition, another calibration curve was also made right after the analysis of that batch samples mentioned above to ensure the RSD\% of the concentrations of all analytes in the analysed samples using two separate calibration curves

Table 5 Stability of levoglucosan, mannosan, galactosan, arabitol and mannitol in standards at $4{ }^{\circ} \mathrm{C}(n=4)$

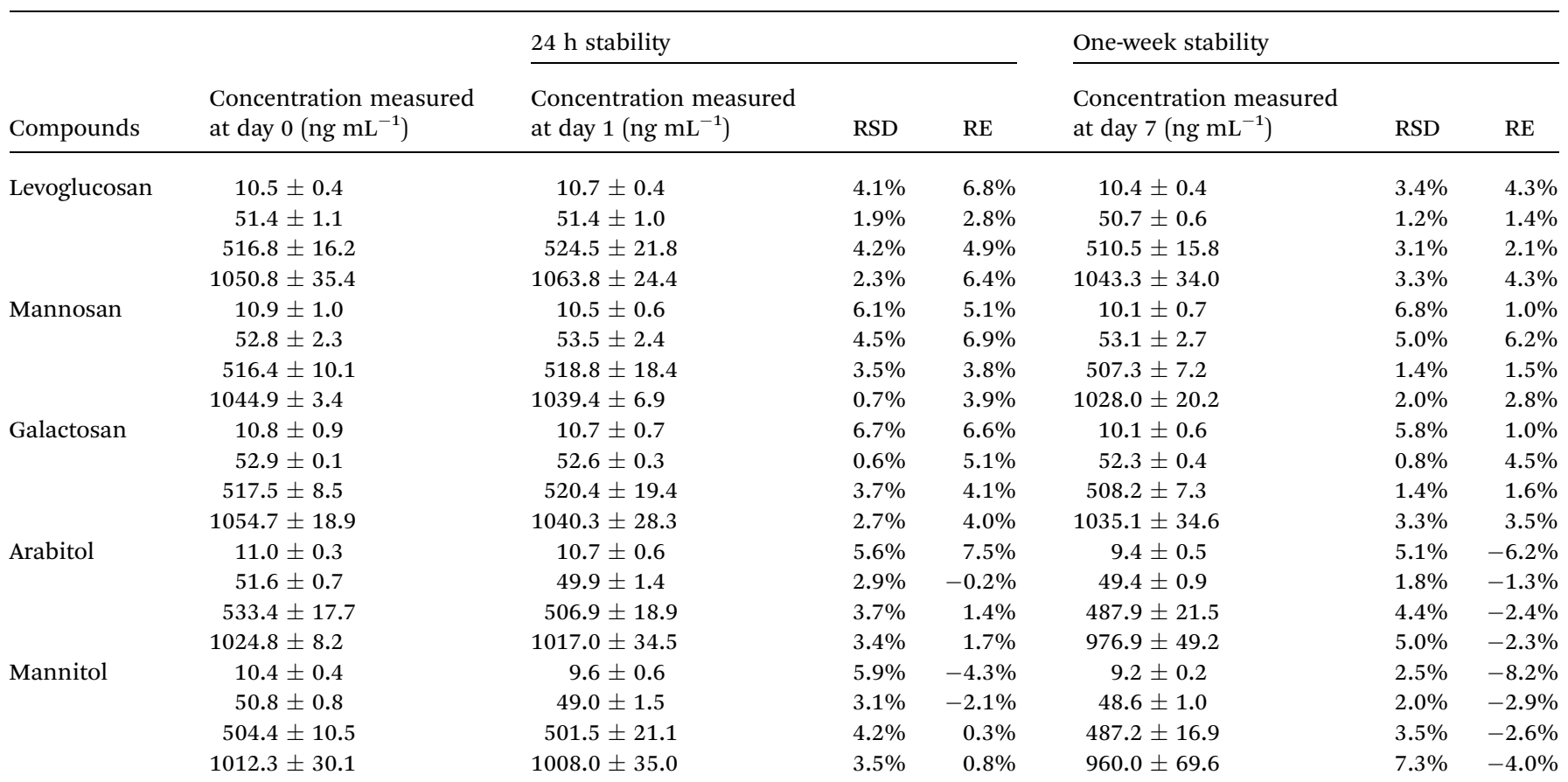


Table 6 The concentrations of levoglucosan, mannosan, galactosan, arabitol and mannitol in PM 2.5 samples by applying the new HPLC-MS/MS method

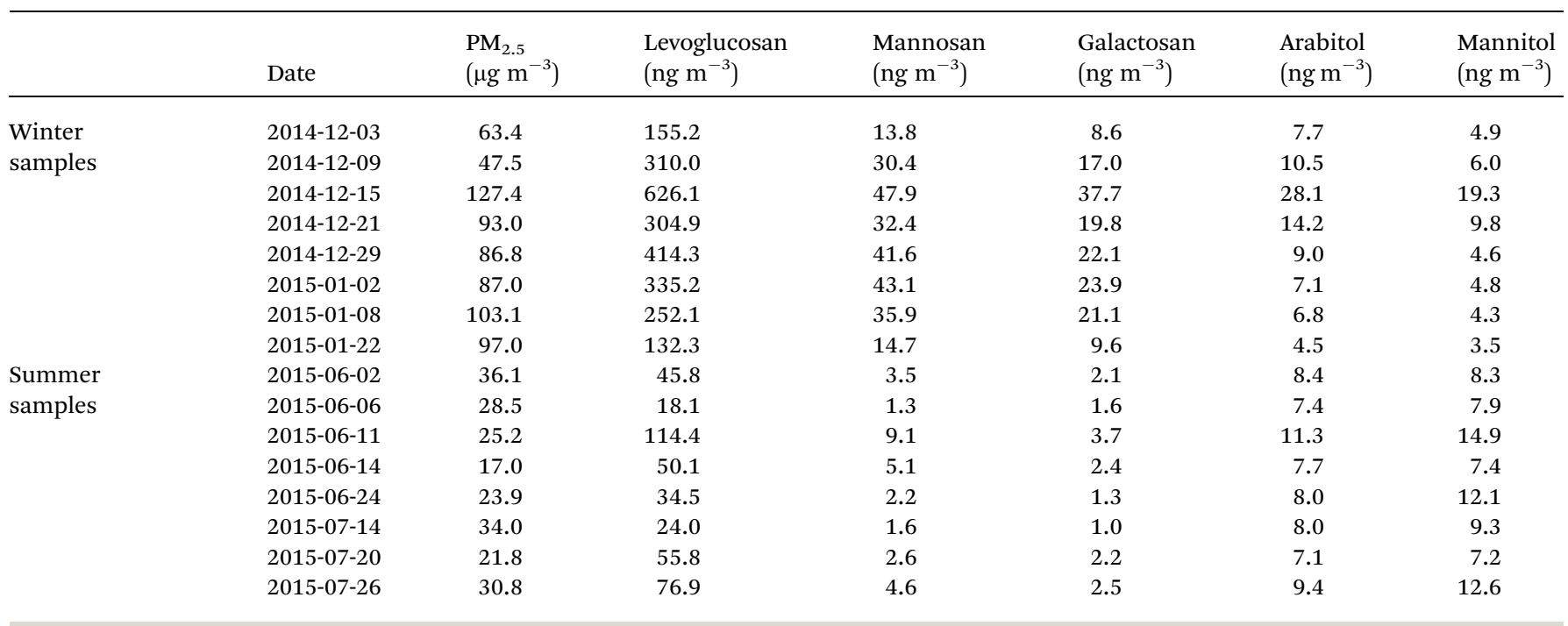

were all $<5 \%$, otherwise those particular samples which did not meet such a requirement would have to be re-analysed. Furthermore, the analytical columns were equilibrated between two injections for 3 minutes, for which the same LC parameters were employed as for the sample analysis. Every two weeks, without injecting the mobile phase into MS, the columns were flushed with $200 \mathrm{mmol} \mathrm{L}^{-1}$ sodium hydroxide solution at a flow rate of $0.4 \mathrm{~mL} \mathrm{~min}^{-1}$ for $24 \mathrm{~h}$ for the removal of residues to maintain their good performance. ${ }^{58,61}$

The aerosol samples were extracted by standard extraction procedure as mentioned earlier in the Experimental section. The concentrations of biomarkers in sample extracts $\left(\mathrm{ng} \mathrm{mL} \mathrm{m}^{-1}\right)$ were converted into their corresponding concentrations in the atmosphere $\left(\mathrm{ng} \mathrm{m}^{-3}\right)$. The results showed a successful application of this newly developed method to identify and quantify these five biomarkers of interest at various pollution levels $\left(\mathrm{PM}_{2.5}: 17.0-127.4 \mu \mathrm{g} \mathrm{m}^{-3}\right)$. During the sampling period, levoglucosan concentrations ranged between $18.1-626.1 \mathrm{ng} \mathrm{m}^{-3}$, with average values of $316.3 \pm 155.9$ and $52.5 \pm 31.2 \mathrm{ng} \mathrm{m}^{-3}$ during winter and summer periods, respectively. As presented in Table 7, it is in good agreement with those measured in Brno, Czech Republic and Shanghai, China, ${ }^{87,88}$ but higher than those obtained in Hong Kong, ${ }^{89}$ where less aerosol pollution is often found compared to the area in this study. ${ }^{90}$ The concentrations of galactosan in winter and summer periods were $20.0 \pm 9.1$ and $2.1 \pm 0.8 \mathrm{ng} \mathrm{m}^{-3}$, which are consistent with the results reported in Belgium during winter $\left.\left(19.6 \mathrm{ng} \mathrm{m}^{-3}\right)\right)^{47}$ and Maine, USA during summer $\left(1.1 \mathrm{ng} \mathrm{m}^{-3}\right),{ }^{91}$ respectively. The arabitol and mannitol in this study were $11.0( \pm 7.5)$ and $7.1 \mathrm{ng} \mathrm{m}^{-3}( \pm 5.3)$ during winter and $8.4( \pm 1.4)$ and $10.0 \mathrm{ng} \mathrm{m}^{-3}( \pm 2.9)$ during summer, respectively, which are lower than those obtained in $\mathrm{PM}_{10}$ samples of Vienna during summer, ${ }^{31}$ but comparable to

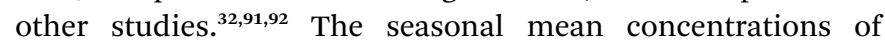
mannosan were $32.5 \pm 12.6$ and $3.8 \pm 2.6 \mathrm{ng} \mathrm{m}^{-3}$ during winter and summer, respectively. A study in another Chinese city Chengdu revealed comparable levoglucosan and mannosan

Table 7 Literature data of the concentrations of levoglucosan, mannosan, galactosan, arabitol and mannitol (ng $\mathrm{m}^{-3}$ ) in aerosol samples

\begin{tabular}{|c|c|c|c|c|c|c|c|c|}
\hline Sampling location & Samples & Sampling period & Levoglucosan & Mannosan & Galactosan & Arabitol & Mannitol & References \\
\hline Brno, Czech & \multirow[t]{2}{*}{$\mathrm{PM}_{2.5}$} & Winter & $326 \pm 114$ & $73.4 \pm 23.4$ & $34.9 \pm 6.13$ & - & - & \multirow[t]{2}{*}{87} \\
\hline Republic & & Summer & $47.1 \pm 26.4$ & $24.0 \pm 2.95$ & $18.9 \pm 1.85$ & - & - & \\
\hline Budapest & $\mathrm{PM}_{10}$ & Feb-Mar 2014 & 387 & 28 & 16 & 7.5 & 4.7 & 92 \\
\hline Maine, USA & $\begin{array}{l}\text { Aerosol } \\
(>1 \mu \mathrm{m})\end{array}$ & $\begin{array}{l}\text { Summer } \\
\text { (Jul 2002) }\end{array}$ & 54.0 & 7.6 & 1.1 & 5.0 & 5.8 & 91 \\
\hline Chengdu, China & $\mathrm{PM}_{2.5}$ & Apr-May 2009 & 396.5 & 21.9 & - & 21.5 & 43.9 & 35 \\
\hline \multirow[t]{2}{*}{ Hong Kong, China } & \multirow[t]{2}{*}{$\mathrm{PM}_{2.5}$} & Winter & 190 & - & - & - & 6.0 & \multirow[t]{2}{*}{89} \\
\hline & & Summer & 35.2 & - & - & - & 3.5 & \\
\hline \multirow[t]{2}{*}{ Shanghai, China } & \multirow[t]{2}{*}{$\mathrm{PM}_{2.5}$} & Winter & 392.2 & 126.5 & - & 7.3 & 36.8 & \multirow[t]{2}{*}{88} \\
\hline & & Summer & 46.5 & 9.2 & - & 14.9 & 172.7 & \\
\hline Ningbo, China & $\mathrm{PM}_{2.5}$ & Winter & $316.3 \pm 155.9$ & $32.5 \pm 12.6$ & $20.0 \pm 9.1$ & $11.0 \pm 7.5$ & $7.1 \pm 5.3$ & This study \\
\hline
\end{tabular}


concentrations, but relatively higher arabitol $\left(21.5 \mathrm{ng} \mathrm{m}^{-3}\right)$ and

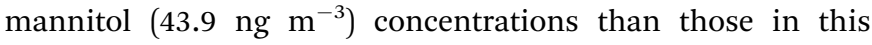
study. ${ }^{35}$ They explained such unexpectedly higher levels of sugar alcohols were mainly influenced by biomass burning plumes during a biomass burning season from April to May 2009. In our study, biomass burning may have also contributed to fungal spore tracers, as the maximum values of sugar alcohols coincided with the peak levels of biomass burning tracers on December 15, 2014.

\section{Conclusions}

A pure water based ultrasonic extraction integrated with HPLCMS/MS method has been developed in this study for the fast and simultaneous measurement of three primary biomass burning tracers (levoglucosan, mannosan, and galactosan) and two fungal spore tracers (arabitol, and mannitol). The effective identification of representative parent and product ion pairs for each tracer can be acquired using the MRM acquisition mode and their separation are also achieved based on the optimized oven temperature, eluent flow rate and concentration; in addition, the operating condition for tandem mass spectrometry has also been determined using flow injection analysis. This newly developed method has been proved simple, reliable and effective in terms of its good calibration curve linearity, sensitivity, selectivity, accuracy, precision, reproducibility and stability, which have been demonstrated in the vigorous validation section. Finally, this method has been successfully applied to the environmental fine aerosol samples collected in an eastern coastal city, Ningbo of China, to identify and quantify multiple biomass burning and fungal spore biomarkers at $\mathrm{ng} \mathrm{m}^{-3}$ levels.

\section{Conflicts of interest}

There are no conflicts to declare.

\section{Acknowledgements}

This work was carried out at the International Doctoral Innovation Centre (IDIC). The authors acknowledge the financial supports from State's Key Project of Research and Development Plan of China (2016YFC0201900), Ningbo Innovation Team Project (2017C510001), National Natural Science Foundation of China (41303091, 91544229 \& 21477088), Zhejiang Provincial Applied Research Program for Commonweal Technology (2015C33011) and Natural Science Foundation of Zhejiang Province (LY17B070001).

\section{References}

1 R. J. Yokelson, I. R. Burling, S. P. Urbanski, E. L. Atlas, K. Adachi, P. R. Buseck, C. Wiedinmyer, S. K. Akagi, D. W. Toohey and C. E. Wold, Trace gas and particle emissions from open biomass burning in Mexico, Atmos. Chem. Phys., 2011, 11, 6787-6808.

2 J. Jung, S. Lee, H. Kim, D. Kim, H. Lee and S. Oh, Quantitative determination of the biomass-burning contribution to atmospheric carbonaceous aerosols in Daejeon, Korea, during the rice-harvest period, Atmos. Environ., 2014, 89, 642-650.

3 V. Vakkari, J. P. Beukes, M. Dal Maso, M. Aurela, M. Josipovic and P. G. van Zyl, Major secondary aerosol formation in Southern African open biomass burning plumes, Nat. Geosci., 2018, 11, 580-583.

4 S. A. Mims and F. M. Mims, Fungal spores are transported long distances in smoke from biomass fires, Atmos. Environ., 2004, 38, 651-655.

5 M. Oliveira, H. Ribeiro and I. Abreu, Annual variation of fungal spores in atmosphere of Porto: 2003, Ann. Agric. Environ. Med., 2005, 12, 309-315.

6 J. J. Pu, H. H. Xu, J. He, S. X. Fang and L. X. Zhou, Estimation of regional background concentration of $\mathrm{CO}_{2}$ at Lin'an Station in Yangtze River Delta, China, Atmos. Environ., 2014, 94, 402-408.

7 J. K. M. Brown and M. S. Hovmoller, Epidemiology - Aerial dispersal of pathogens on the global and continental scales and its impact on plant disease, Science, 2002, 297, 537-541.

8 K.-H. Kim, E. Kabir and S. A. Jahan, Airborne bioaerosols and their impact on human health, J. Environ. Sci., 2018, 67, 2335.

9 T. C. Bond, D. G. Streets, K. F. Yarber, S. M. Nelson, J. H. Woo and Z. Klimont, A technology-based global inventory of black and organic carbon emissions from combustion, J. Geophys. Res.: Atmos., 2004, 109, D14203.

10 J. S. Xu, H. H. Xu, H. Xiao, L. Tong, C. E. Snape, C. J. Wang and J. He, Aerosol composition and sources during high and low pollution periods in Ningbo, China, Atmos. Res., 2016, 178, 559-569.

11 G. Engling, J. He, R. Betha and R. Balasubramanian, Assessing the regional impact of indonesian biomass burning emissions based on organic molecular tracers and chemical mass balance modeling, Atmos. Chem. Phys., 2014, 14, 8043-8054.

$12 \mathrm{~J}$. He, B. Zielinska and R. Balasubramanian, Composition of semi-volatile organic compounds in the urban atmosphere of Singapore: influence of biomass burning, Atmos. Chem. Phys., 2010, 10, 11401-11413.

13 S. H. Wang, N. H. Lin, M. D. Chou and J. H. Woo, Estimate of radiative forcing of Asian biomass-burning aerosols during the period of TRACE-P, J. Geophys. Res.: Atmos., 2007, 112, D10222.

14 J. S. Xu, X. H. Tai, R. Betha, J. He and R. Balasubramanian, Comparison of physical and chemical properties of ambient aerosols during the 2009 haze and non-haze periods in Southeast Asia, Environ. Geochem. Health, 2015, 37, 831-841.

15 F. K. Duan, X. D. Liu, T. Yu and H. Cachier, Identification and estimate of biomass burning contribution to the urban aerosol organic carbon concentrations in Beijing, Atmos. Environ., 2004, 38, 1275-1282.

16 P. Sundarambal, R. Balasubramanian, P. Tkalich and J. He, Impact of biomass burning on ocean water quality in Southeast Asia through atmospheric deposition: field observations, Atmos. Chem. Phys., 2010, 10, 11323-11336. 
17 J. E. Pachon, R. J. Weber, X. Zhang, J. A. Mulholland and A. G. Russell, Revising the use of potassium (K) in the source apportionment of $\mathrm{PM}_{2.5}$, Atmos. Pollut. Res., 2013, 4, $14-21$.

18 S. G. Brown, T. Lee, P. T. Roberts and J. L. Collett, Wintertime Residential Biomass Burning in Las Vegas, Nevada; Marker Components and Apportionment Methods, Atmosphere, 2016, 7, 58.

19 H. Puxbaum, A. Caseiro, A. Sanchez-Ochoa, A. Kasper-Giebl, M. Claeys, A. Gelencser, M. Legrand, S. Preunkert and C. Pio, Levoglucosan levels at background sites in Europe for assessing the impact of biomass combustion on the European aerosol background, J. Geophys. Res.: Atmos., 2007, 112, D23S05.

20 C. A. Pio, M. Legrand, C. A. Alves, T. Oliveira, J. Afonso, A. Caseiro, H. Puxbaum, A. Sanchez-Ochoa and A. Gelencser, Chemical composition of atmospheric aerosols during the 2003 summer intense forest fire period, Atmos. Environ., 2008, 42, 7530-7543.

21 Y. Cheng, G. Engling, K. B. He, F. K. Duan, Y. L. Ma, Z. Y. Du, J. M. Liu, M. Zheng and R. J. Weber, Biomass burning contribution to Beijing aerosol, Atmos. Chem. Phys., 2013, 13, 7765-7781.

22 X. Zhang, A. Hecobian, M. Zheng, N. H. Frank and R. J. Weber, Biomass burning impact on $\mathrm{PM}_{2.5}$ over the southeastern US during 2007: integrating chemically speciated FRM filter measurements, MODIS fire counts and PMF analysis, Atmos. Chem. Phys., 2010, 10, 6839-6853.

23 T. Zhang, M. Claeys, H. Cachier, S. Dong, W. Wang, W. Maenhaut and X. Liu, Identification and estimation of the biomass burning contribution to Beijing aerosol using levoglucosan as a molecular marker, Atmos. Environ., 2008, 42, 7013-7021.

24 K. E. Yttri, J. Schnelle-Kreis, W. Maenhaut, G. Abbaszade, C. Alves, A. Bjerke, N. Bonnier, R. Bossi, M. Claeys, C. Dye, M. Evtyugina, D. Garcia-Gacio, R. Hillamo, A. Hoffer, M. Hyder, Y. Iinuma, J. L. Jaffrezo, A. Kasper-Giebl, G. Kiss, P. L. Lopez-Mahia, C. Pio, C. Piot, C. RamirezSanta-Cruz, J. Sciare, K. Teinila, R. Vermeylen, A. Vicente and R. Zimmermann, An intercomparison study of analytical methods used for quantification of levoglucosan in ambient aerosol filter samples, Atmos. Meas. Tech., 2015, 8, 125-147.

25 Q. H. Hu, Z. Q. Xie, X. M. Wang, H. Kang and P. F. Zhang, Levoglucosan indicates high levels of biomass burning aerosols over oceans from the Arctic to Antarctic, Sci. Rep., 2013, 3, 3119.

26 G. Engling, J. J. Lee, H. J. Sie, Y. C. Wu and I. Yet-Pole, Anhydrosugar characteristics in biomass smoke aerosolcase study of environmental influence on particle-size of rice straw burning aerosol, J. Aerosol Sci., 2013, 56, 2-14.

27 C. G. Nolte, J. J. Schauer, G. R. Cass and B. R. T. Simoneit, Highly polar organic compounds present in wood smoke and in the ambient atmosphere, Environ. Sci. Technol, 2001, 35, 1912-1919.

28 L. L. Liang, G. Engling, K. B. He, Z. Y. Du, Y. Cheng and F. K. Duan, Evaluation of fungal spore characteristics in
Beijing, China, based on molecular tracer measurements, Environ. Res. Lett., 2013, 8, 014005.

29 H. Bauer, A. Kasper-Giebl, M. Loflund, H. Giebl, R. Hitzenberger, F. Zibuschka and H. Puxbaum, The contribution of bacteria and fungal spores to the organic carbon content of cloud water, precipitation and aerosols, Atmos. Res., 2002, 64, 109-119.

30 T. Lee, S. A. Grinshpun, D. Martuzevicius, A. Adhikari, C. M. Crawford and T. Reponen, Culturability and concentration of indoor and outdoor airborne fungi in six single-family homes, Atmos. Environ., 2006, 40, 2902-2910.

31 H. Bauer, M. Claeys, R. Vermeylen, E. Schueller, G. Weinke, A. Berger and H. Puxbaum, Arabitol and mannitol as tracers for the quantification of airborne fungal spores, Atmos. Environ., 2008, 42, 588-593.

32 T. Zhang, G. Engling, C. Y. Chan, Y. N. Zhang, Z. S. Zhang, M. Lin, X. F. Sang, Y. D. Li and Y. S. Li, Contribution of fungal spores to particulate matter in a tropical rainforest, Environ. Res. Lett., 2010, 5, 024010.

$33 \mathrm{~J}$. He and R. Balasubramanian, Determination of Atmospheric Polycyclic Aromatic Hydrocarbons Using Accelerated Solvent Extraction, Anal. Lett., 2009, 42, 16031619.

34 L. Liang, G. Engling, Z. Du, F. Duan, Y. Cheng, X. Liu and $\mathrm{K}$. He, Contribution of fungal spores to organic carbon in ambient aerosols in Beijing, China, Atmos. Pollut. Res., 2017, 8, 351-358.

35 Y. H. Yang, C. Y. Chan, J. Tao, M. Lin, G. Engling, Z. S. Zhang, T. Zhang and L. Su, Observation of elevated fungal tracers due to biomass burning in the Sichuan Basin at Chengdu City, China, Sci. Total Environ., 2012, 431, 68-77.

36 W. Zhu, Z. Cheng, L. Luo, S. Lou, Y. Ma and N. Yan, Investigation of fungal spore characteristics in $\mathrm{PM}_{2.5}$ through organic tracers in Shanghai, China, Atmos. Pollut. Res., 2018, 9, 894-900.

37 P. Di Filippo, D. Pomata, C. Riccardi, F. Buiarelli and C. Perrino, Fungal contribution to size-segregated aerosol measured through biomarkers, Atmos. Environ., 2013, 64, 132-140.

38 Y. Jia and M. Fraser, Characterization of Saccharides in Sizefractionated Ambient Particulate Matter and Aerosol Sources: The Contribution of Primary Biological Aerosol Particles (PBAPs) and Soil to Ambient Particulate Matter, Environ. Sci. Technol., 2011, 45, 930-936.

39 A. Carvalho, C. Pio and C. Santos, Water-soluble hydroxylated organic compounds in German and Finnish aerosols, Atmos. Environ., 2003, 37, 1775-1783.

$40 \mathrm{~W}$. Elbert, P. E. Taylor, M. O. Andreae and U. Poschl, Contribution of fungi to primary biogenic aerosols in the atmosphere: wet and dry discharged spores, carbohydrates, and inorganic ions, Atmos. Chem. Phys., 2007, 7, 4569-4588.

41 F. Buiarelli, S. Canepari, P. Di Filippo, C. Perrino, D. Pomata, C. Riccardi and R. Speziale, Extraction and analysis of fungal spore biomarkers in atmospheric bioaerosol by HPLC-MSMS and GC-MS, Talanta, 2013, 105, 142-151.

42 R. C. Urban, M. Lima-Souza, L. Caetano-Silva, M. E. C. Queiroz, R. F. P. Nogueira, A. G. Allen, 
A. A. Cardoso, G. Held and M. Campos, Use of levoglucosan, potassium, and water-soluble organic carbon to characterize the origins of biomass-burning aerosols, Atmos. Environ., 2012, 61, 562-569.

43 C. Dye and K. E. Yttri, Determination of monosaccharide anhydrides in atmospheric aerosols by use of highperformance liquid chromatography combined with highresolution mass spectrometry, Anal. Chem., 2005, 77, 18531858.

44 P. M. Medeiros and B. R. T. Simoneit, Analysis of sugars in environmental samples by gas chromatography-mass spectrometry, J. Chromatogr. A, 2007, 1141, 271-278.

45 R. C. Urban, C. A. Alves, A. G. Allen, A. A. Cardoso, M. E. C. Queiroz and M. L. A. M. Campos, Sugar markers in aerosol particles from an agro-industrial region in Brazil, Atmos. Environ., 2014, 90, 106-112.

46 D. Pomata, P. Di Filippo, C. Riccardi, F. Buiarelli and V. Gallo, Determination of non-certified levoglucosan, sugar polyols and ergosterol in NIST Standard Reference Material 1649a, Atmos. Environ., 2014, 84, 332-338.

47 Z. Zdrahal, J. Oliveira, R. Vermeylen, M. Claeys and W. Maenhaut, Improved method for quantifying levoglucosan and related monosaccharide anhydrides in atmospheric aerosols and application to samples from urban and tropical locations, Environ. Sci. Technol., 2002, 36, 747-753.

48 R. L. Cordell, I. R. White and P. S. Monks, Validation of an assay for the determination of levoglucosan and associated monosaccharide anhydrides for the quantification of wood smoke in atmospheric aerosol, Anal. Bioanal. Chem., 2014, 406, 5283-5292.

49 K. Saarnio, K. Teinila, M. Aurela, H. Timonen and R. Hillamo, High-performance anion-exchange chromatography-mass spectrometry method for determination of levoglucosan, mannosan, and galactosan in atmospheric fine particulate matter, Anal. Bioanal. Chem., 2010, 398, 2253-2264.

50 A. Caseiro, I. L. Marr, M. Claeys, A. Kasper-Giebl, H. Puxbaum and C. A. Pio, Determination of saccharides in atmospheric aerosol using anion-exchange highperformance liquid chromatography and pulsedamperometric detection, J. Chromatogr. A, 2007, 1171, 37-45.

51 F. Mashayeky Rad, S. Spinicci, S. Silvergren, U. Nilsson and R. Westerholm, Validation of a HILIC/ESI-MS/MS method for the wood burning marker levoglucosan and its isomers in airborne particulate matter, Chemosphere, 2018, 211, 617-623.

52 A. Gambaro, R. Zangrando, P. Gabrielli, C. Barbante and P. Cescon, Direct determination of levoglucosan at the picogram per milliliter level in Antarctic ice by highperformance liquid chromatography/electrospray ionization triple quadrupole mass spectrometry, Anal. Chem., 2008, 80, 1649-1655.

53 K. E. Yttri, D. Simpson, J. K. Nojgaard, K. Kristensen, J. Genberg, K. Stenstrom, E. Swietlicki, R. Hillamo, M. Aurela, H. Bauer, J. H. Offenberg, M. Jaoui, C. Dye, S. Eckhardt, J. F. Burkhart, A. Stohl and M. Glasius, Source apportionment of the summer time carbonaceous aerosol at Nordic rural background sites, Atmos. Chem. Phys., 2011, 11, 13339-13357.

54 K. Saarnio, K. Teinila, S. Saarikoski, S. Carbone, S. Gilardoni, H. Timonen, M. Aurela and R. Hillamo, Online determination of levoglucosan in ambient aerosols with particle-into-liquid sampler - high-performance anionexchange chromatography - mass spectrometry (PILSHPAEC-MS), Atmos. Meas. Tech., 2013, 6, 2839-2849.

55 G. Schkolnik and Y. Rudich, Detection and quantification of levoglucosan in atmospheric aerosols: A review, Anal. Bioanal. Chem., 2006, 385, 26-33.

56 Y. Iinuma, G. Engling, H. Puxbaum and H. Herrmann, A highly resolved anion-exchange chromatographic method for determination of saccharidic tracers for biomass combustion and primary bio-particles in atmospheric aerosol, Atmos. Environ., 2009, 43, 1367-1371.

57 P. Yao, V. F. Schwab, V. N. Roth, B. Q. Xu, T. D. Yao and G. Gleixner, Levoglucosan concentrations in ice-core samples from the Tibetan Plateau determined by reversephase high-performance liquid chromatography mass spectrometry, J. Glaciol., 2013, 59, 599-612.

58 C. Piot, J. L. Jaffrezo, J. Cozic, N. Pissot, I. El Haddad, N. Marchand and J. L. Besombes, Quantification of levoglucosan and its isomers by high performance liquid chromatography - electrospray ionization tandem mass spectrometry and its applications to atmospheric and soil samples, Atmos. Meas. Tech., 2012, 5, 141-148.

59 J. He, R. Balasubramanian, S. Karthikeyan and U. M. Joshi, Determination of semi-volatile organochlorine compounds in the atmosphere of Singapore using accelerated solvent extraction, Chemosphere, 2009, 75, 640-648.

60 J. W. Dolan, Mobile-Phase Degassing: What, Why, and How, LCGC North Am., 2014, 32, 482.

61 ThermoFisher. Dionex CarbonPac MA1, 2013, https:// www.thermofisher.com/order/catalog/product/044066.

62 P. J. Birbara and T. A. Nalette, Process for removing free and dissolved $\mathrm{CO}_{2}$ from aqueous solutions, US Pat., US5525237A, 1996.

63 M. Novič, B. Lečnik, V. Hudnik and B. Pihlar, Carbonate interferences by ion chromatographic determination of anions in mineral waters, J. Chromatogr. A, 1997, 764, 249256.

64 S. Olafsson, D. Whittington, J. Murray, M. Regnier and F. Moussavi-Harami, Fast and sensitive HPLC-MS/MS method for direct quantification of intracellular deoxyribonucleoside triphosphates from tissue and cells, $J$. Chromatogr. B: Anal. Technol. Biomed. Life Sci., 2017, 10681069, 90-97.

65 M. S. Wilm and M. Mann, Electrospray and Taylor-Cone theory, Dole's beam of macromolecules at last?, Int. J. Mass Spectrom. Ion Processes, 1994, 136, 167-180.

66 J. S. Page, R. T. Kelly, K. Tang and R. D. Smith, Ionization and Transmission Efficiency in an Electrospray Ionization-Mass Spectrometry Interface, J. Am. Soc. Mass Spectrom., 2007, 18, 1582-1590. 
67 G. Hopfgartner, K. Bean, J. Henion and R. Henry, Ion spray mass spectrometric detection for liquid chromatography: a concentration-or a mass-flow-sensitive device?, $J$. Chromatogr. A, 1993, 647, 51-61.

68 S. Gilardoni, E. Vignati, F. Cavalli, J. P. Putaud, B. R. Larsen, M. Karl, K. Stenstrom, J. Genberg, S. Henne and F. Dentener, Better constraints on sources of carbonaceous aerosols using a combined C-14 - macro tracer analysis in a European rural background site, Atmos. Chem. Phys, 2011, 11, 5685-5700.

69 W. Wang, M. H. Wu, L. Li, T. Zhang, X. D. Liu, J. L. Feng, H. J. Li, Y. J. Wang, G. Y. Sheng, M. Claeys and J. M. Fu, Polar organic tracers in $\mathbf{P M}_{2.5}$ aerosols from forests in eastern China, Atmos. Chem. Phys., 2008, 8, 7507-7518.

70 Y. Yang, C.-y. Chan, J. Tao, M. Lin, G. Engling, Z. Zhang, T. Zhang and L. Su, Observation of elevated fungal tracers due to biomass burning in the Sichuan Basin at Chengdu City, China, Sci. Total Environ., 2012, 431, 68-77.

71 E. C. H. Wan and J. Z. Yu, Determination of sugar compounds in atmospheric aerosols by liquid chromatography combined with positive electrospray ionization mass spectrometry, J. Chromatogr. A, 2006, 1107, 175-181.

72 EPA, 40 CFR Appendix B to Part 136 Definition and Procedure for the Determination of the Method Detection Limit Revision 2, U.S. Environmental Protection Agency, 2012.

73 X. Zheng, Y. Wu, S. J. Zhang, J. N. Hu, K. M. Zhang, Z. H. Li, L. Q. He and J. M. Hao, Characterizing particulate polycyclic aromatic hydrocarbon emissions from diesel vehicles using a portable emissions measurement system, Sci. Rep., 2017, 7, 10058.

74 C. J. Tsai, C. H. Huang, Y. C. Lin, T. S. Shih and B. H. Shih, Field test of a porous-metal denuder sampler, Aerosol Sci. Technol., 2003, 37, 967-974.

75 C. J. Tsai, C. H. Huang and H. H. Lu, Adsorption capacity of a nylon filter of filter pack system for $\mathrm{HCl}$ and $\mathrm{HNO}_{3}$ gases, Sep. Sci. Technol., 2004, 39, 629-643.

76 M. J. Wright, R. L. Thomas, P. E. Stanford and A. R. Horvath, Multiple Reaction Monitoring with Multistage Fragmentation (MRM3) Detection Enhances Selectivity for LC-MS/MS Analysis of Plasma Free Metanephrines, Clin. Chem., 2015, 61, 505-513.

77 Q. Liu, X. Liao, J. Xu, J. Zhao, J. Luo and L. Kong, Development and validation of a sensitive and selective LC-MS/MS method for the determination of trans $\delta$ veniferin, a resveratrol dehydrodimer, in rat plasma and its application to pharmacokinetics and bioavailability studies, J. Chromatogr. B: Anal. Technol. Biomed. Life Sci., 2014, 958, 124-129.

78 X. Wang, J. Ren, S. Zhu, G. Ren, L. Wang, X. Chen, Z. Qiu and C. Zhang, Pharmacokinetics and tissue distribution of eupatilin and its metabolite in rats by an HPLC-MS/MS method, J. Pharm. Biomed. Anal., 2018, 159, 113-118.

79 C. Hess, K. Sydow, T. Kueting, M. Kraemer and A. Maas, Considerations regarding the validation of chromatographic mass spectrometric methods for the quantification of endogenous substances in forensics, Forensic Sci. Int., 2018, 283, 150-155.

80 X. Zhao, B. Wang, K. Xie, J. Liu, Y. Zhang, Y. Wang, Y. Guo, G. Zhang, G. Dai and J. Wang, Development and comparison of HPLC-MS/MS and UPLC-MS/MS methods for determining eight coccidiostats in beef, J. Chromatogr. B: Anal. Technol. Biomed. Life Sci., 2018, 1087-1088, 98-107.

81 T. A. Little, BioPharm International, Editon edn., 2016, vol. 29.

82 R. W. Dixon and G. Baltzell, Determination of levoglucosan in atmospheric aerosols using high performance liquid chromatography with aerosol charge detection, $J$. Chromatogr. A, 2006, 1109, 214-221.

83 H. Sillén, M. Cook and P. Davis, Determination of ticagrelor and two metabolites in plasma samples by liquid chromatography and mass spectrometry, J. Chromatogr. B: Anal. Technol. Biomed. Life Sci., 2010, 878, 2299-2306.

84 E. G. Nouman, M. A. Al-Ghobashy and H. M. Lotfy, Development and validation of LC-MSMS assay for the determination of the prodrug dabigatran etexilate and its active metabolites in human plasma, J. Chromatogr. B: Anal. Technol. Biomed. Life Sci., 2015, 989, 37-45.

85 H. Gu, Y. Deng, J. Wang, A.-F. Aubry and M. E. Arnold, Development and validation of sensitive and selective LCMS/MS methods for the determination of BMS-708163, a $\gamma$ secretase inhibitor, in plasma and cerebrospinal fluid using deprotonated or formate adduct ions as precursor ions, J. Chromatogr. B: Anal. Technol. Biomed. Life Sci., 2010, 878, 2319-2326.

86 M. D. Weingarten, FDA final guidance on bioanalytical method validation, 2018, https:/www.fda.gov/downloads/drugs/ guidances/ucm070107.Pdf.

87 K. Křơmal, P. Mikuška, M. Vojtěšek and Z. Večeřa, Seasonal variations of monosaccharide anhydrides in $\mathrm{PM}_{1}$ and $\mathrm{PM}_{2.5}$ aerosol in urban areas, Atmos. Environ., 2010, 44, 5148-5155.

88 M. Xiao, Q. Wang, X. Qin, G. Yu and C. Deng, Composition, sources, and distribution of $\mathrm{PM}_{2.5}$ saccharides in a coastal urban site of China, Atmosphere, 2018, 9, 274.

89 E. C. H. Wan and J. Z. Yu, Analysis of sugars and sugar polyols in atmospheric aerosols by chloride attachment in liquid chromatography/negative ion electrospray mass spectrometry, Environ. Sci. Technol., 2007, 41, 2459-2466.

90 J. Tao, L. M. Zhang, J. J. Cao and R. J. Zhang, A review of current knowledge concerning $\mathrm{PM}_{2.5}$ chemical composition, aerosol optical properties and their relationships across China, Atmos. Chem. Phys., 2017, 17, 9485-9518.

91 P. M. Medeiros, M. H. Conte, J. C. Weber and B. R. T. Simoneit, Sugars as source indicators of biogenic organic carbon in aerosols collected above the Howland Experimental Forest, Maine, Atmos. Environ., 2006, 40, 1694-1705.

92 I. Salma, Z. Nemeth, T. Weidinger, W. Maenhaut, M. Claeys, M. Molnar, I. Major, T. Ajtai, N. Utry and Z. Bozoki, Source apportionment of carbonaceous chemical species to fossil fuel combustion, biomass burning and biogenic emissions by a coupled radiocarbon-levoglucosan marker method, Atmos. Chem. Phys., 2017, 17, 13767-13781. 